\title{
ANALISIS KINERJA KEUANGAN MELALUI RASIO KEUANGAN PADA PT. GUDANG GARAM, Tbk YANG TERDAFTAR DI BURSA EFEK INDONESIA
}

\author{
Oleh: \\ Cindy Eveline Sitanggang \\ S1 Manajemen \\ Darwin Lie, Parman Tarigan, Ady Inrawan
}

Abstraksi

Tujuan penelitian ini adalah: 1) Untuk mengetahui dan menganalisis kinerja keuangan pada PT. Gudang Garam, Tbk bila diukur dengan rasio keuangan dari tahun 2009 sampai dengan tahun 2014. 2) Untuk mengetahui faktor-faktor yang menyebabkan terjadinya penurunan kinerja keuangan PT. Gudang Garam, Tbk dari tahun 2009 sampai dengan tahun 2014.

Penelitian ini dilakukan dengan menggunakan data kualitatif dan data kuantitatif. Objek penelitian yang diteliti adalah PT. Gudang Garam, Tbk yang terdaftar di Bursa Efek Indonesia. Sumber data yang digunakan penulis dalam penelitian ini adalah data sekunder yang diperoleh dari website http://www.idx.co.id. Metode pengumpulan data dilakukan dengan menggunakan metode dokumentasi. Pada penelitian ini penulis menggunakan alat analisis antara lain: current ratio, quick ratio, total debt to total asset ratio, total debt to equity ratio, inventory turnover, fixed asset turnover, asset turnover, net profit margin, return on asset dan return on equity.

Berdasarkan hasil penelitian, dapat disimpulkan bahwa kinerja keuangan PT. Gudang Garam, Tbk dari tahun 2009 sampai dengan tahun 2014 yang diukur melalui rasio profitabilitas cenderung mengalami penurunan. Penurunan kinerja keuangan disebabkan oleh rasio aktivitas dan rasio solvabilitas (leverage).

Hasil penelitian menyarankan sebaiknya PT. Gudang Garam, Tbk tetap melakukan analisis laporan keuangan secara keseluruhan dan rutin, dan juga meningkatkan aktiva lancarnya serta menekan persentase kenaikan hutang perusahaan.

Kata kunci: Analisis Rasio Keuangan, Kinerja Keuangan.

\section{Abstract}

Cindy Eveline Sitanggang, Analysis of Financial Performance is measured by Financial Ratios at PT. Gudang Garam, Tbk Listed on the Indonesia Stock Exchange. Consulted by Mr. Dr. Darwin Lie, SE, MM, as the Chairman Consultant, Mr. P. Tarigan, SE, MM, as the First Consultant, and Mr. Ady Inrawan, SE, MM, as the Second Consultant.

The purpose of this research are: 1) To investigate and analyze financial performance at PT. Gudang Garam, Tbk listed on the Indonesia Stock Exchange is measured by financial ratios from 2009 until 2014. 2) To determine the factors that caused the decline in financial performance at PT. Gudang Garam, Tbk from 2009 until 2014.

This research was done by using qualitative data and quantitative data. Object of this research is PT. Gudang Garam, Tbk listed on the Indonesia Stock Exchange. Source of research data is secondary data obtained from website http://www.idx.co.id. The method of data collection is done by using the method of documentation. In this research, the author using analytical tools such as: current ratio, quick ratio, total debt to total asset ratio, total debt to equity ratio, inventory turnover, fixed asset turnover, asset turnover, net profit margin, return on asset dan return on equity.

Based on the result, it can be concluded that the company's overall financial performance at PT. Gudang Garam, Tbk from 2009 until 2014 is measured by profitability ratio tend to decrease. Decline in financial performance due to the activity ratio and solvency ratio (leverage).

The result of this research suggest that PT. Gudang Garam, Tbk should continue the overall financial ratio analysis and should increase current assets and reduce the company's debts.

Keywords: Financial Ratio Analysis, Financial Performance.

\section{A. PENDAhuluan}

1. Latar Belakang Masalah

Pada umumnya setiap perusahaan memiliki tujuan yang sama dalam hal mendapatkan laba perusahaan, mengalami pertumbuhan dan juga demi mempertahankan kelangsungan hidup perusahaan. Untuk mencapai tujuan tersebut, semua pihak dan bagian perusahaan diharapkan mampu bekerja sama dengan baik dan memahami tugas serta tanggungjawab masing-masing. Laporan keuangan yang dihasilkan oleh suatu perusahaan merupakan salah satu sumber informasi mengenai posisi keuangan, kinerja keuangan dan juga perubahan posisi keuangan yang sangat berguna bagi sejumlah pemakai laporan keuangan dalam pengambilan keputusan. Agar dapat mengetahui kondisi kesehatan perusahaan serta prestasi yang telah dicapai maka perlu dilakukan analisis terhadap laporan keuangan. 
Alat ukur yang biasanya digunakan adalah rasio keuangan.

Melalui analisis rasio keuangan, maka dapat dilihat baik ataupun buruknya kondisi keuangan perusahaan dan juga untuk mengetahui tingkat profitabilitas suatu perusahaan. Profitabilitas adalah kemampuan perusahaan untuk menghasilkan laba. Apabila tingkat profitabilitas perusahaan tinggi maka daya saing perusahaan juga akan semakin meningkat. Profitabilitas yang tinggi juga membuka peluang perusahaan untuk berekspansi sehingga membuka kesempatan investasi yang baru. Rasio profitabilitas itu sendiri terbagi atas Return on Asset (ROA), Return on Equity (ROE) dan Net Profit Margin (NPM)

Berikut ini adalah gambaran Return on Asset (ROA), Return on Equity (ROE) dan Net Profit Margin (NPM) pada PT. Gudang Garam, Tbk yang terdaftar di Bursa Efek Indonesia periode 2009 2014.

Tabel 1

Gambaran Net Profit Margin (NPM), Return on

Asset (ROA) dan Return on Equity (ROE) PT.

Gudang Garam, Tbk yang Terdaftar di Bursa Efek Indonesia Periode 2009 - 2014

\begin{tabular}{|c|c|c|c|c|c|c|}
\hline \multirow[b]{2}{*}{ Yastabsl } & \multicolumn{6}{|c|}{ 12bua } \\
\hline & $x c e$ & 2010 & $20+1$ & 30.2 & mis: & $20+4$ \\
\hline 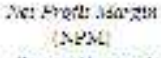 & $111+28 \times 4$ & 11,00 क & $118=6$ & $x$ cins & isn & 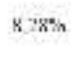 \\
\hline $\begin{array}{c}\text { Rement inst } \\
(\mathrm{ROA})\end{array}$ & 120096 & $21,+3 \%$ & {$[2, \mathrm{c} \% \mathrm{~s}$} & $4.80 \times 6$ & $8,0.1 \%$ & $1,1,10$ \\
\hline 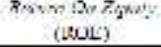 & 18 8s:- & 18.358: & 10.34. & Q. $8 \mathrm{n}^{\mathrm{n}} \mathrm{x}$ & $+23^{\circ}$ & lii 745 \\
\hline
\end{tabular}

Pada Tabel 1 dapat dilihat bahwa Net Profit Margin (NPM), Return On Asset (ROA) dan Return On Equity (ROE) dari tahun 2009 sampai dengan tahun 2014 cenderung mengalami penurunan. Penurunan ini disebabkan oleh tidak optimalnya kemampuan perusahaan dalam mengelola aset yang dimilikinya dan tidak optimalnya kemampuan perusahaan untuk meningkatkan persentase penjualannya. Selain itu, besarnya beban pokok penjualan, beban usaha, beban pajak dan beban lainnya yang dimiliki perusahaan menyebabkan persentase laba bersih menjadi lebih sedikit dari persentase penjualan, modal dan total aset. Hal inilah yang menyebabkan Net Profit Margin (NPM), Return On Asset (ROA) dan Return On Equity (ROE) cenderung menurun yaitu persentase kenaikan laba bersih dari tahun ke tahun lebih kecil dibandingkan persentase kenaikan penjualan, total aset dan modal perusahaan.

\section{Rumusan Masalah}

a. Bagaimana kinerja keuangan PT. Gudang Garam, Tbk bila diukur dengan rasio keuangan tahun 2009 - 2014?

b. Faktor-faktor apa saja yang menyebabkan terjadinya penurunan kinerja keuangan PT. Gudang Garam, Tbk tahun 2009 - 2014?

\section{Tujuan Penelitian}

a. Untuk mengetahui dan menganalisis kinerja keuangan pada PT. Gudang Garam, Tbk bila diukur dengan rasio keuangan tahun 2009 2014.

b. Untuk mengetahui faktor-faktor yang menyebabkan terjadinya penurunan kinerja keuangan PT. Gudang Garam, Tbk tahun 2009 -2014 .

\section{Metode Penelitian}

Adapun yang menjadi objek penelitian adalah PT. Gudang Garam, Tbk yang terdaftar di Bursa Efek Indonesia dengan memperoleh data-data perusahaan melalui website: http://www.idx.co.id dan www.gudanggaramtbk.com.

Adapun desain penelitian yang digunakan penulis dalam penelitian ini adalah penelitian kepustakaan (library research). Sumber data yang digunakan penulis dalam penelitian ini adalah data sekunder. Data sekunder ini merupakan data yang sifatnya mendukung keperluan data primer seperti buku-buku, literatur dan bacaan yang berkaitan dengan masalah yang diteliti. Data sekunder diperoleh dari website http://www.idx.co.id serta sumber yang lainnya.

Adapun jenis data yang digunakan dalam penelitian ini adalah jenis data kualitatif dan data kuantitatif. Hasil data yang diperoleh dari lapangan akan dianalisis secara deskriptif dan komparatif.

\section{B. LANDASAN TEORI}

\section{Manajemen Keuangan}

Menurut Sutrisno (2013:3), manajemen keuangan adalah semua aktivitas perusahaan yang berhubungan dengan usaha-usaha mendapatkan dana perusahaan dengan biaya yang murah serta usaha untuk menggunakan dan mengalokasikan dana tersebut secara efisien. Sedangkan menurut Keown, et. al. (2008:4), manajemen keuangan berkepentingan dengan bagaimana cara menciptakan dan menjaga nilai ekonomis atau kekayaan. Berdasarkan pendapat para ahli di atas maka penulis menyimpulkan manajemen keuangan adalah suatu kegiatan perusahaan yang menyangkut bagaimana perusahaan memperoleh dana, bagaimana perusahaan mengelola dana serta bagaimana perusahaan mengelola aset untuk memperoleh laba ataupun profit perusahaan.

Menurut Sutrisno (2013:5), fungsi manajemen keuangan terdiri dari tiga keputusan utama yang harus dilakukan oleh suatu perusahaan yaitu keputusan investasi, keputusan pendanaan dan keputusan dividen

\section{Kinerja Keuangan}

Menurut Sawir (2005:1), kinerja keuangan adalah ukuran mengenai seberapa jauh perusahaanperusahaan berada dari batas normal agar perusahaan dapat dikatakan sehat dan berjalan baik sehingga dapat memenuhi kewajibannya dan menghasilkan keuntungan di masa mendatang. Selanjutnya menurut Fahmi (2011:2), kinerja keuangan merupakan suatu analisis yang dilakukan untuk melihat sejauh mana suatu perusahaan telah 
melaksanakan dengan menggunakan aturan-aturan pelaksanaan keuangan secara baik dan benar.

Berdasarkan keterangan para ahli di atas, maka dapat disimpulkan bahwa kinerja keuangan adalah analisis yang dilakukan oleh perusahaan untuk mengetahui sejauh mana keberhasilan perusahaan dalam menghasilkan profit atau laba sehingga perusahaan dapat merencanakan kegiatan untuk peningkatan prestasinya. Kinerja keuangan dapat diukur melalui analisis rasio keuangan. Adapun rasio keuangan yang digunakan adalah rasio profitabilitas.

\section{Laporan Keuangan}

Menurut Sutrisno (2013:8), laporan keuangan merupakan hasil akhir dari proses akuntansi yang meliputi dua laporan utama yakni neraca dan laporan rugi-laba. Laporan keuangan disusun dengan maksud untuk menyediakan informasi keuangan suatu perusahaan kepada pihak-pihak yang berkepentingan sebagai bahan pertimbangan di dalam mengambil keputusan. Sedangkan menurut Sudana (2011:15), laporan keuangan terdiri dari dua yaitu laporan laba rugi (income statement) dan neraca (balance sheet). Neraca (balance sheet) menggambarkan posisi keuangan perusahaan pada saat atau tanggal tertentu. Pada neraca tampak posisi aktiva, yang merupakan hasil keputusan investasi yang diambil oleh manajemen perusahaan dan passiva yang merupakan sumber-sumber keuangan untuk mendanai investasi aktiva tersebut pada suatu saat tertentu.

Berdasarkan keterangan para ahli di atas maka dapat disimpulkan bahwa laporan keuangan secara garis besar terdiri dari neraca atau laporan posisi keuangan perusahaan dan laporan laba rugi. Laporan tersebut menggambarkan bagaimana kondisi keuangan dari perusahaan yang kemudian akan menjadi bahan informasi dan juga masukan bagi pihak-pihak yang berkepentingan.

\section{Pengaruh Analisis Laporan Keuangan}

Menurut Astuti (2004:29), analisis laporan keuangan adalah segala sesuatu yang menyangkut penggunaan informasi akuntansi untuk membuat keputusan bisnis dan investasi. Sedangkan menurut Harahap (2006:190), analisis laporan keuangan adalah menguraikan pos-pos laporan keuangan menjadi unit informasi yang lebih kecil dan melihat hubungannya yang bersifat signifikan atau yang mempunyai makna antara yang satu dengan yang lain baik antara data kuantitatif maupun data non kuantitatif dengan tujuan untuk mengetahui kondisi keuangan lebih dalam yang sangat penting dalam proses menghasilkan keputusan yang tepat.

Jadi dapat disimpulkan bahwa analisis laporan keuangan adalah suatu proses penelitian laporan keuangan beserta komponennya yang bertujuan untuk mengevaluasi hasil-hasil yang telah diperoleh di masa lalu dan juga memprediksi kondisi keuangan di masa yang akan datang.

\section{Rasio Keuangan}

Menurut Horne dan John (2012:163), rasio keuangan adalah alat yang digunakan untuk menghubungkan dua buah data keuangan dengan membagi satu angka dengan angka lainnya. Selanjutnya menurut Astuti (2004:29), rasio keuangan adalah penggunaan informasi akuntansi yang dirancang untuk membantu mengevaluasi laporan keuangan. Sedangkan menurut Munawir (2007:37), rasio keuangan adalah suatu metode analisa untuk mengetahui hubungan dari pos-pos tertentu dalam neraca atau laporan laba rugi secara individu atau kombinasi dari kedua laporan tersebut. Secara umum rasio keuangan dibagi menjadi empat jenis yaitu rasio likuiditas, rasio solvabilitas (leverage), rasio aktivitas dan rasio profitabilitas.

\section{PEMBAHASAN}

1. Analisa

a. Rasio Likuiditas

Rasio likuiditas adalah rasio yang bertujuan untuk mengetahui kemampuan perusahaan dalam membayar kewajiban jangka pendek. Berikut ini rasio likuiditas pada PT. Gudang Garam, Tbk pada tahun 2009 - 2014:

\section{1) Current Ratio}

Current ratio adalah pengukuran yang digunakan secara luas untuk mengevaluasi likuiditas perusahaan dan kemampuan membayar utang jangka pendek. Current ratio atau yang biasa disebut rasio lancar dapat dihitung dengan rumus:

$$
\text { Rasio Lancar }=\frac{\text { Aset Lancar }}{\text { Kewajiban Lancar }} \times 100 \%
$$

Current Ratio PT. Gudang Garam, Tbk dapat dilihat pada Tabel 2 berikut ini:

Tabel 2

Current Ratio PT. Gudang Garam, Tbk Tahun 20092014

(dalam jutaan rupiah)

\begin{tabular}{|c|c|c|c|}
\hline Gasun & Nort lancar & IIntang 1, ancar & Carreni Rosic \\
\hline $2 c e s$ & $10.5 \$ 1.539$ & 7961.278 & $26,0 \%$ \\
\hline 7000 & $22 \cos 404$ & $1-281+a k$ & 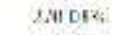 \\
\hline $\mathrm{x}+\mathrm{T}$ & we ts: & 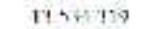 & ․․ $15 \%$ \\
\hline$x: ?$ & $200: 4031$ & 13.90797 & $217,00 \%$ \\
\hline 701 & $\therefore \mathrm{eC4}-\mathrm{nt}$ & $712<450$ & 12728 \\
\hline 204 & 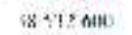 & $74: 5 x-14$ & $1920: \%$ \\
\hline
\end{tabular}

Sumber: www.idx.co.id, diolah

\section{2) Quick Ratio}

Quick ratio menunjukkan kemampuan aktiva lancar yang paling likuid yang mampu menutupi utang lancar tanpa mengutamakan persediaan. Quick ratio atau rasio cepat dapat dihitung dengan rumus:

$$
\text { Rasio Cepat }=\frac{\text { Aset Lancar }- \text { Persediaan }}{\begin{array}{c}
\text { Kewajiban Lancar } \\
100 \%
\end{array}} \mathrm{x}
$$

Quick Ratio PT. Gudang Garam, Tbk dapat dilihat pada Tabel 3 berikut ini:

Tabel 3

Quick Ratio PT. Gudang Garam, Tbk Tahun 2009. 2014

(dalam jutaan rupiah) 


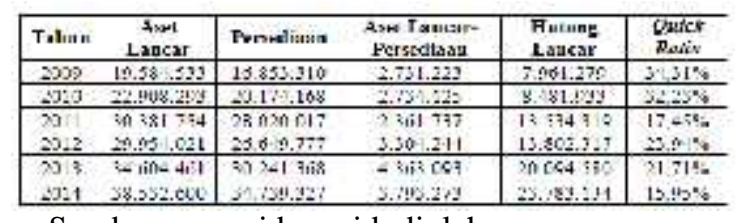

Sumber: www.idx.co.id, diolah

\section{b. Rasio Solvabilitas}

Berikut ini adalah rasio solvabilitas PT. Gudang Garam, Tbk tahun 2009 - 2014.

\section{1) Total Debt To Asset Ratio}

Total debt to asset ratio (DAR) adalah rasio total hutang dengan total aktiva yang biasa disebut rasio hutang, mengukur persentase besarnya dana yang berasal dari hutang. Rumus untuk mencari total debt to asset ratio adalah:

Total Debt To Asset Ratio $=\frac{\text { Total Hutang }}{\text { Total Aktiva }}$ x $100 \%$

Total debt to asset ratio pada PT. Gudang Garam, Tbk dapat dilihat pada tabel 4 berikut ini:

$$
\text { Tabel } 4
$$

Total Debt To Asset Ratio PT. Gudang Garam, Tbk Tahun 2009-2014

\begin{tabular}{|c|c|c|c|}
\hline \multicolumn{4}{|c|}{ (dalam jutaan rupiah) } \\
\hline $200 \mathrm{Co}$ & $\frac{1010}{8.813: 124}$ & $\frac{1740.250 .553}{27.250}$ & 320 \\
\hline 2016 & $9 .+21+03$ & $30.7-1.679$ & $30,055^{2}$ \\
\hline $20 \mathrm{~L}$. & -1.537 .777 & 30.088 .705 & $37.10^{0 / 2}$ \\
\hline 2012 & $\therefore+403.5: 2$ & $41.39 y .328$ & $32,90 \%$, \\
\hline 2013 & 1.353 .983 & 30.770 .21 & $12200 \%$ \\
\hline 3011 & 21991897 & 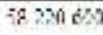 & $12.90 \%$ \\
\hline
\end{tabular}

Sumber: www.idx.co.id, diolah

\section{2) Total Debt To Equity Ratio}

Rumusnya adalah:

Total Debt To Equity Ratio= $\frac{\text { Total Hutang }}{\text { Modal }}$ x 100\%

Total debt to equity ratio pada PT. Gudang Garam, Tbk dapat dilihat pada tabel 5 berikut ini:

$$
\text { Tabel } 5
$$

Total Debt To Equity Ratio PT. Gudang Garam, Tbk

\begin{tabular}{|c|c|c|c|}
\hline \multicolumn{4}{|c|}{ (dalam jutaan rupiah) } \\
\hline Talinm & Toral TIntang & Sotala1 & Toss Dear Y O EG EAS REAt? \\
\hline 2006 & 3. $8+5 .-24$ & $18, \pm 0,29$ & $48,3, \%$ \\
\hline 2010 & 9.12. 03 & 21.197 .102 & $11,5 \%$ \\
\hline 2011 & $14.35 i .1 \%$ & 24.30 .428 & $5,21 \%$ \\
\hline 2012 & 14.933 .6 .2 & 20.605 .713 & 96,026 \\
\hline 2013 & $21.3 \times 3.960$ & $2 y+4.32 \%$ & $2, y^{4} 4$ \\
\hline 2014 & 24.971 .88$. & S..t25/2S & $0,21 \%$ \\
\hline
\end{tabular}
Tahun 2009-2014

Sumber: www.idx.co.id, diolah

\section{c. Rasio Aktivitas}

Berikut ini adalah rasio aktivitas pada PT Gudang Garam, Tbk tahun 2009 - 2014:

\section{1) Inventory Turnover}

Rumus untuk menghitung perputaran persediaan adalah:

$$
\text { Inventory Turnover }=\frac{\text { Penjualan }}{\text { Persediaan }} \times 1 \text { kali }
$$

Inventory turnover pada PT. Gudang Garam, Tbk dapat dilihat pada tabel 6 berikut ini:

$$
\text { Tabel } 6
$$

\begin{tabular}{|c|c|c|c|}
\hline Tatuu & Peajualan & Penxuliasa & misurary rumsive \\
\hline 300 & 12. 9n ces? & $1584 ? 510$ & ift ali \\
\hline 20.0 & 37.981 .507 & 20.174 .108 & . \\
\hline $20: 1$ & $11.89 \div .252$ & 28.026017 & $20 \mathrm{zzli}$ \\
\hline $2 \mathrm{C} .2$ & $45.223 .6 S$ & 23.648 .777 & $.84 s+1 i$ \\
\hline 7D) 4 & $\because 4<9 \mathrm{ca}$ & $41 \% 4 \times x$ & R4 zalt \\
\hline 7011 & An:sheso & $\sin \times 2 z$ & xy nt \\
\hline
\end{tabular}

Inventory Turnover PT. Gudang Garam, Tbk Tahun 2009-2014

(dalam jutaan rupiah)

\section{2) Fixed Asset Turnover}

Rumus untuk menghitung perputaran aktiva tetap adalah:

Perputaran Aktiva Tetap $=\frac{\text { Penjualan }}{\text { Total Aktiva Tetap }} \times 1 \mathrm{kali}$

Fixed asset turnover pada PT. Gudang Garam, Tbk dapat dilihat pada tabel 7 berikut ini:

Tabel 7

\begin{tabular}{|c|c|c|c|}
\hline Tahren & Penģninian n & Akrriva Torap & Fued Ass' Turnon: \\
\hline 2000 & $7364+160$ & 20: 4 tet & - s a kait \\
\hline :a11 & HCe: 45 & $243 \times 3 ?$ & Sor kais \\
\hline 2011 & 1: .881552 & 8.29.88: & $5,: 1 \mathrm{kati}$ \\
\hline 2012 & $19.02 ! .600$ & 10.380 .326 & 9.72 kati \\
\hline 2013 & 95476074 & $147 \mathrm{kB} \mathrm{915}$ & $375 \mathrm{ks} / \mathrm{i}$ \\
\hline 201 & cs. $18: .8=0$ & $18, r_{i j} .2 / 2$ &, $11 \mathrm{kmils}$ \\
\hline
\end{tabular}

Fixed Asset Turnover PT. Gudang Garam, Tbk

Tahun 2009-2014

(dalam jutaan rupiah)

Sumber: www.idx.co.id, diolah

\section{3) Total Asset Turnover} rumus:

Perputaran total aset dapat dihitung melalui

$$
\text { Perputaran Total Aset }=\frac{\text { Penjualan }}{\text { Perputaran Total Aset }} \times 1 \mathrm{kali}
$$

Total asset turnover pada PT. Gudang Garam, Tbk

\begin{tabular}{|c|c|c|c|}
\hline \multicolumn{4}{|c|}{$\begin{array}{l}\text { Tahun 2009-2014 } \\
\text { (dalam jutaan rupiah) }\end{array}$} \\
\hline Tahizm & Rwajnalnin & Toral Like & Inta' Assed Turnows \\
\hline 2319 & 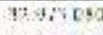 & $8280150 \%$ & $2.21 \mathrm{~min}$ \\
\hline$\$ 210$ & $91,5+1.5 ;$ & $30.141 .6: 7$ & $223 \pm 11$ \\
\hline N111 & 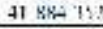 & $34 a \times 8,0$, & 1. Wizall \\
\hline Sa12 & $10028 \mathrm{e} \times 5$ & it $\sin 125$ & $5.18 \mathrm{mli}$ \\
\hline 3114 & $\because \sin 094$ & 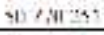 & anw zai1 \\
\hline 201 & 63.185 .850 & $38.2 \times 0.000$ & $2,12 \mathrm{hLi}$ \\
\hline
\end{tabular}
dapat dilihat pada tabel 8 berikut ini:

$$
\text { Tabel } 8
$$

Total Asset Turnover PT. Gudang Garam, Tbk Tahun 2009-2014

Sumber: www.idx.co.id, diolah

\section{d. Rasio Profitabilitas}

Berikut ini adalah rasio profitabilitas pada PT. Gudang Garam, Tbk tahun 2009-2014

Tabel 9

Rasio Profitabilitas PT. Gudang Garam, Tbk Tahun

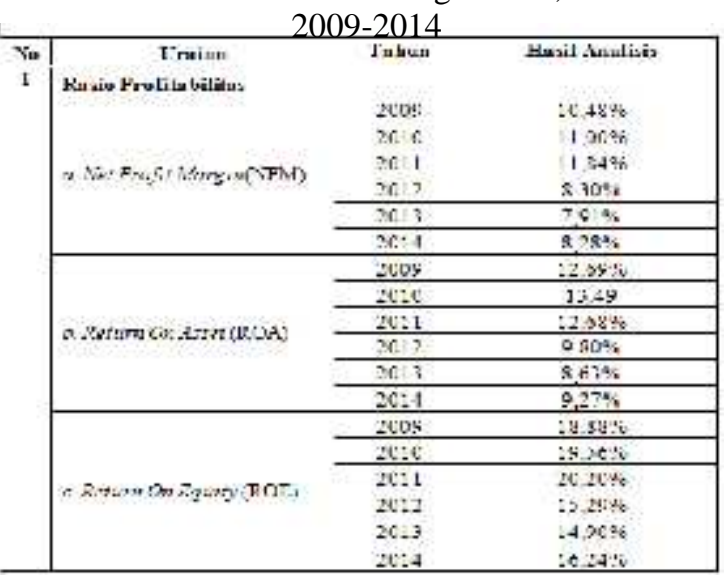


Sumber: www.idx.co.id, diolah

\section{1) Net Profit Margin (NPM)}

Merupakan rasio yang menggambarkan kemampuan perusahaan untuk menghasilkan keuntungan dibandingkan dengan penjualan yang dicapai. Rumus untuk mencari marjin laba bersih adalah:

Marjin laba bersih $=\frac{\text { Laba bersih sete.ah pajak }}{\text { Xa }} \times 100 \%$ Pexjualan

Net profit margin pada PT. Gudang Garam, Tbk dapat dilihat pada tabel 10 berikut ini:

Tabel 10

Net Profit Margin PT. Gudang Garam, Tbk Tahun 2009-2014 (dalam iutaan rupiah)

\begin{tabular}{|c|c|c|c|}
\hline Tuhun & 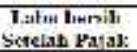 & Treeijuntun & 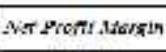 \\
\hline 206 & $3.115,7 \mathrm{NZ}$ & 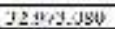 & $10,18 \div 6$ \\
\hline 3010 & $-4 \mathrm{i} 253$ & 97 i61 277 & 11 का? \\
\hline 2ni & $-\operatorname{cis} i n$ & $4.854=52$ & $11=-46$ \\
\hline 2012 & 0.008 .114 & 19.V12:.y:10 & $\mathrm{s}, \mathrm{y} 0 \mathrm{C}$ \\
\hline 2013 & -983092 & 55491254 & $78 \%$ \\
\hline 2014 & $3.155,4 y$ & $\cos 1 \%, \sin 0$ & $5,28=$ \\
\hline
\end{tabular}

Sumber: www.idx.co.id, diolah

\section{2) Return On Asset (ROA)}

Return on Asset (ROA) menggambarkan perputaran aktiva. Semakin besar rasio ini semakin baik. Hal ini berarti bahwa aktiva dapat lebih cepat berputar dan meraih laba. Rumus untuk mencari Return On Asset adalah:

Return on Asset $(\mathrm{ROA})=$ Laba bersih setelah pajak $\times 100 \%$

$$
\text { Iotal aset }
$$

Return on Asset (ROA) pada PT. Gudang Garam, Tbk dapat dilihat pada tabel 11 berikut ini:

Tabel 11

Return On Asset PT. Gudang Garam, Tbk Tahun 2009-2014

\begin{tabular}{|c|c|c|c|}
\hline 1atun & $\begin{array}{l}\text { Lalla birith } \\
\text { Sactah } P_{3} \mid 2 k\end{array}$ & Iotz .15et & 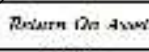 \\
\hline 2003 & $3 .+5: 5 x^{2}$ & 27.230 .958 & $12.09^{9}$ \\
\hline No10 & 1.15 .282 & 30.711 .598 & 13.94 \\
\hline 2011 & 4.931 .122 & 39.088 .72 & 12,085 \\
\hline 2012 & 1.56572 & 1.200 .22 & $9,8 \mathrm{C}_{3}$ \\
\hline 2013 & 4.313932 & 50.770 .25 & 8,639 \\
\hline 4411 & $\therefore\{9,13 t$ & $8 \% 1 \times 0$ & $4 \%, \%$ \\
\hline
\end{tabular}

Sumber: www.idx.co.id, diolah

\section{3) Return On Equity (ROE)}

Rasio ini menggambarkan kemampuan perusahaan dalam menghasilkan keuntungan dengan modal sendiri yang dimiliki. Rasio ini menunjukkan berapa persen laba bila diukur dari modal pemilik. Semakin besar rasio ini semakin bagus. Rumus untuk mencari ROE adalah: Return on Equity $(\mathrm{ROE})=\frac{\text { Laba bersil setelah pajak }}{\text { Noda sendin }} \times 100 \%$

Return on Equity (ROE) pada PT. Gudang Garam, Tbk dapat dilihat pada tabel 12 berikut ini:

$$
\text { Tabel } 12
$$

Return On Equity PT. Gudang Garam, Tbk Tahun

\begin{tabular}{|c|c|c|c|}
\hline Tahnin & $\begin{array}{l}\text { Laba berlih } \\
\text { Satclat Pajal: }\end{array}$ & Mndal & Restarn on $E_{q i z}$ \\
\hline $\begin{array}{l}2000 \\
200\end{array}$ & $\begin{array}{l}3 / 59.182 \\
1.19 .282\end{array}$ & 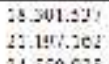 & $\begin{array}{l}14,58 \% \\
11,5 \% \%\end{array}$ \\
\hline$\frac{20.1}{20.2}$ & $\frac{4.933 .102}{1.0 j 3.71}$ & $\frac{2+.550 .528}{26,005.5 .3}$ & $\frac{20,29 \%}{15,23 \%}$ \\
\hline 195 & $4>R=Q 4: !$ & $90-16 \%$ & $142 \% \mathrm{Ki}$ \\
\hline 201 & 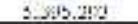 & $13 \% 2,92$ & $10,21 \%$ \\
\hline
\end{tabular}
2009-2014
Sumber: www.idx.co.id, diolah

\section{Evaluasi}

Kinerja keuangan dapat diukur menggunakan rasio keuangan untuk mengetahui kondisi keuangan perusahaan. Kinerja keuangan pada PT. Gudang Garam, Tbk diukur melalui rasio keuangan yaitu:

\section{a. Rasio Likuiditas}

\section{1) Rasio Lancar}

Menurut Munawir (2002:278), menyatakan bahwa tingkat likuiditas current ratio sesuai dengan pedoman untuk perusahaan yang dianggap baik adalah nilai tersebut memiliki arti bahwa current ratio perusahaan $2: 1$ atau $200 \%$, di mana dengan current ratio sebesar 2,00 maka setiap Rp1,00 utang lancar dapat dijamin dengan aktiva lancar sebesar Rp2,00. Berikut ini adalah tabel rata-rata current ratio pada PT. Gudang Garam, Tbk:

$$
\text { Tabel } 13
$$

Rata-rata Current Ratio PT. Gudang Garam, Tbk

\begin{tabular}{|c|c|c|c|c|}
\hline Tahus & Ask Lancar & Hulaug Laacas & Curreu Katio & Rala-rata \\
\hline 2009 & $19.59-.533$ & 7.56 .279 & $24500 \%$ & \multirow{6}{*}{$113,00 \%$} \\
\hline 2010 & 22.973 .293 & $3.48: 933$ & $275,08 \%$ & \\
\hline 2011 & 30381.731 & 23.531310 & $2218 \%$ & \\
\hline 2012 & $29.95 \div \mathrm{CH}$ & 35.802 .317 & 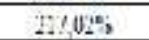 & \\
\hline 2013 & $34.525 .46:$ & 20.064 .580 & $172.21 \%$ & \\
\hline 2014 & 36532.000 & 23./83.234 & 262,$0 ;$ & \\
\hline
\end{tabular}
Tahun 2009-2014

(dalam jutaan rupiah)

Sumber: www.idx.co.id, diolah

Berdasarkan nilai rata-rata current ratio, dapat dilihat bahwa 2 tahun terakhir dimulai dari tahun 2013 sampai tahun 2014, current ratio berada di bawah rata-rata. Sedangkan tahun-tahun sebelumnya berada di atas rata-rata. Secara keseluruhan current ratio cenderung menurun dari tahun ke tahun dikarenakan pertumbuhan hutang lancar yang besar. Hal ini dapat terjadi karena perusahaan kurang efisien dalam mengelola aset lancar yang dimilikinya.

\section{2) Rasio Cepat (Quick Ratio)}

Melalui rasio ini dapat diketahui kemampuan perusahaan dalam melunasi hutang-hutang jangka pendeknya tanpa memperhitungkan persediaan. Menurut Syamsuddin (2013:45), dinyatakan quick ratio sebesar 1,0 atau $100 \%$ pada umumnya sudah dianggap baik. Dan dapat diartikan bahwa setiap $\mathrm{Rp}$ 1,00 hutang lancar dapat dibiayai dengan Rp1,00 aktiva lancar.

Tabel 14

Rata-rata Quick Ratio

PT. Gudang Garam, Tbk Tahun 2009-2014(dalam

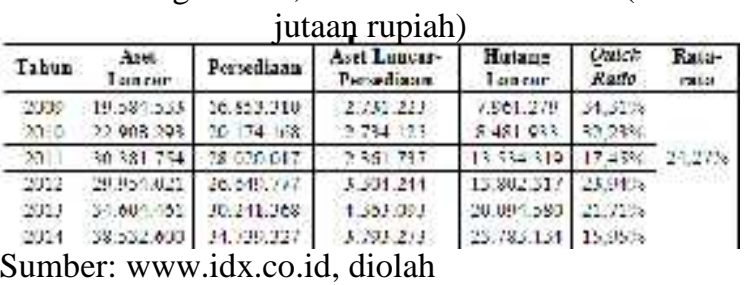

Berdasarkan nilai rata-rata quick ratio, dapat dilihat bahwa quick ratio dari tahun 2011 sampai 
tahun 2014 berada di bawah nilai rata-rata. Secara keseluruhan quick ratio berada di bawah rata-rata dan cenderung menurun disebabkan jumlah persediaan yang besar (di atas $80 \%$ ) dari aset lancar. Sehingga jumlah aktiva lancar yang likuid menjadi sedikit. Untuk meningkatkan tingkat likuiditasnya, maka perusahaan perlu meningkatan aktiva lancar yang likuid seperti kas dan piutang. Semakin tinggi quick ratio atau lebih dari $100 \%$ maka kinerja perusahaan semakin baik.

\section{b. Rasio Solvabilitas}

\section{1) Total Debt To Asset Ratio}

Rasio ini disebut dengan rasio hutang yang mengukur persentase besarnya dana yang berasal dari hutang. Semakin rendah rasio ini, maka resiko perusahaan tidak mampu membayar likuiditasnya semakin kecil.

Tabel 15

Rata-rata Total Debt To Asset Ratio (DAR) PT. Gudang Garam, Tbk

(dalam jutaan rupiah)

\begin{tabular}{|c|c|c|c|c|}
\hline Tahum & $\begin{array}{l}\text { Tam1 } \\
\text { Hucxis: }\end{array}$ & Tarsl test & $\begin{array}{l}\text { Tould Debt To Aosot } \\
\text { Ratio }\end{array}$ & Rars-rsth \\
\hline 2009 & 8.818 .121 & 27.230 .955 & $32,1 \geqslant \%$ & \multirow{6}{*}{$35.8, \pi$} \\
\hline $20: 0$ & $0.2116=$ & $30.4: 6 \%$ & $30,65 \%$ & \\
\hline $20: 1$ & $\$ 1537.737$ & 39.088 .725 & $37,19 \%$ & \\
\hline 2012 & :490:012 & 11.30 .323 & $35.57 \%$ & \\
\hline $20: 2$ & $21353 S 36$ & 50.770 .251 & $12,05 \%$ & \\
\hline $26: 2$ & $21991.88 \mathrm{CO}$ & $58.220 .6 \times 0$ & 12,$9 ; \%$ & \\
\hline
\end{tabular}

Dilihat dari nilai rata-rata, total debt to asset ratio (DAR) pada tahun 2009, 2010 dan 2012 berada di bawah nilai rata-rata. Hal ini berarti semakin kecil persentase jumlah aktiva perusahaan yang dibiayai oleh utang. Secara keseluruhan total debt to asset ratio (DAR) yang dimiliki perusahaan cenderung meningkat. Hal ini disebabkan oleh total hutang perusahaan yang selalu meningkat setiap tahunnya dan tidak diimbangi dengan kemampuan perusahaan untuk mengelola aset yang dimilikinya. Semakin tinggi rasio ini maka semakin tinggi pula risiko kebangkrutan yang dimiliki oleh perusahaan dan semakin besar jumlah modal pinjaman yang digunakan dalam menghasilkan profit bagi perusahaan.

\section{2) Total Debt To Equity Ratio}

Berikut ini adalah tabel dan grafik rata-rata total debt to equity ratio:

$$
\text { Tabel } 16
$$

Rata-rata Total Debt To Equity Ratio PT. Gudang Garam, Tbk

Tahun 2009-2014

(dalam jutaan rupiah)

\begin{tabular}{|c|c|c|c|c|}
\hline Takux & I stal Hutang & Nodoal & $\begin{array}{l}\text { Then Dabr ho Lquit: } \\
\text { Fntiu }\end{array}$ & $\begin{array}{c}\text { Futu- } \\
\text { rata }\end{array}$ \\
\hline 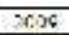 & 5.ganat & 8.301527 & $18,3^{k R_{6}}$ & \\
\hline$x: 0$ & $9.42140 \%$ & $21.19: 62$ & $42,42 \%$ & \\
\hline$-\mathrm{c}: 1$ & $:-.2817 \%$ & $24,2,00918$ & $24.21 \%$ & $x, 9024$ \\
\hline $3: 9$ & 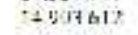 & Xifing 17 & का $12: 4$ & \\
\hline $20: 3$ & 21.353 1980 & $23.4162 \%$ & $2,2,46$ & \\
\hline$x: 4$ & $24.5: 11850$ & $34.2 .8>0$ & $2.21 \%$ & \\
\hline
\end{tabular}

Sumber: www.idx.co.id, diolah

Dilihat dari nilai rata-rata, total debt to equity ratio berada di atas rata-rata pada 2 tahun terakhir yaitu tahun 2013 sampai tahun 2014. Hal ini berarti semakin besar modal yang digunakan untuk menjamin utang perusahaan. Total debt to equity ratio (DER) cenderung mengalami kenaikan. Kenaikan rasio ini disebabkan oleh kenaikan total hutang yang terus menerus dari tahun ke tahun. Hal ini menunjukkan bahwa kemampuan perusahaan semakin menurun dalam memenuhi kewajibannya dan semakin besar risiko bisnis yang dihadapi terutama apabila kondisi perekonomian memburuk.

\section{c. Rasio Aktivitas}

\section{1) Inventory Turnover}

Semakin tinggi persediaan berputar, maka semakin efektif perusahaan dalam mengelola persediaannya.

Tabel 17

Rata- rata Inventory Turnover PT. Gudang Garam, Tbk Tahun 2009-2014

(dalam jutaan rupiah)

\begin{tabular}{|c|c|c|c|c|}
\hline Tulum & Pinjeslue & Prominum & Lusarners Imos rar & sat \\
\hline 5010 & :71901807 & $38.17+168$ & s7: & \multirow{5}{*}{ :st isalh } \\
\hline air. & 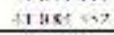 & sal:sian, & $10 \operatorname{coh}$ & \\
\hline$x+?$ & $460250 \mathrm{~F}$ & 9641077 & stezh & \\
\hline Sulj & $2.193 .7: 1$ & 36.211 .63 & $\therefore$ s $;$ sith & \\
\hline 3014 & $6918 \times 5 \div 8$ & 44719387 & 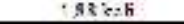 & \\
\hline
\end{tabular}

Sumber: www.idx.co.id, diolah

Dilihat dari nilai rata-rata, inventory turnover pada tahun 2011 berada di bawah nilai rata-rata. Hal ini menunjukkan dana yang tertanam dalam persediaan berputar lebih sedikit. Dan pada tahun 2009, 2010, 2012, 2013 dan 2014 inventory turnover berada di atas nilai rata-rata. Hal ini menunjukkan dana yang tertanam dalam persediaan berputar lebih banyak. Inventory turnover cenderung sejajar atau rata. Kecenderungan ini menunjukkan bahwa tidak optimalnya kemampuan perusahaan dalam mengelola persediaan. Sehingga perusahaan kurang efisien dalam melaksanakan kegiatan operasionalnya.

\section{2) Fixed Asset Turnover}

Berikut ini adalah tabel rata-rata dan grafik fixed asset turnover.

Tabel 18

Rata-rata Fixed Asset Turnover PT. Gudang Garam, Tbk

(dalam jutaan rupiah)

\begin{tabular}{|c|c|c|c|c|}
\hline & & & Trend Actur & Rata rata \\
\hline Thamen & {$[" m] n 313 n$} & Akntra I map & Turreever & \\
\hline 0 & $4-621057$ & $74063=$ & 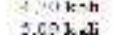 & \\
\hline 20.1 & 41.854 .352 & $8 . .39381$ & $B_{1}-1 k .2 i$ & 1. तो saln \\
\hline 20.2 & 49.028 .696 & $-0.335: 25$ & $-72 \mathrm{kJli}$ & \\
\hline sto & $7 \times 9 i+424$ & te sin & & \\
\hline$x \cdot 0$ & $A \times 15=x \times D$ & $+1 \times 4: 3 \times 28$ & $A / k-h$ & \\
\hline
\end{tabular}

Sumber: www.idx.co.id, diolah

Dilihat dari nilai rata-rata, fixed asset turnover 2 tahun terakhir yaitu tahun 2013 sampai dengan tahun 2014 berada di bawah nilai rata-rata. Hal ini berarti semakin kecil kemampuan dana yang tertanam dalam aset tetap berputar selama satu tahun. Sedangkan pada tahun 2009 sampai dengan tahun 2012 berada di atas nilai rata-rata. Hal ini berarti semakin besar kemampuan dana yang tertanam dalam aset tetap berputar selama satu tahun. Fixed asset turnover cenderung mengalami penurunan. Hal ini disebabkan oleh kurang optimalnya perusahaan di dalam mengelola aktiva tetap yang dimilikinya. 


\section{3) Total Asset Turnover}

Semakin besar perputaran aktiva, maka semakin efektif dan efisien pengelolaan dan penggunaan seluruh aktiva yang dimiliki oleh perusahaan.

Tabel 19

Rata-rata Total Asset Turnover PT. Gudang Garam, Tbk

Tahun 2009-2014

(dalam jutaan rupiah)

\begin{tabular}{|c|c|c|c|c|}
\hline \\
\hline I abuu & Penjualan & I & $T_{\text {rumatizer }}$ & Ratarata \\
\hline 2009 & 32973.680 & 27.230 .965 &., $2 \mathrm{~J} \mathrm{kabi}$ & \\
\hline 2010 & $3759 \mathrm{~L} . \mathrm{S97}$ & $30.741 .67 \mathrm{~s}$ & $.22 \mathrm{kahi}$ & \\
\hline 201 & 41.584 .392 & 39.095 .705 & $\ldots j$ kali & 1,21 :ahi \\
\hline 2012 & 15.228 .696 & 41.509 .325 &,$- 18 \mathrm{k} \cdot \mathrm{ili}$ & \\
\hline 2013 & 55 LSESS4 & $50.770 .25 \mathrm{t}$ & $.09 \mathrm{k} 2 \mathrm{li}$ & \\
\hline 2014 & 65185.950 & 53.220 .600 & $\ldots 12 \mathrm{kali}$ & \\
\hline
\end{tabular}

Sumber: www.idx.co.id, diolah

Dilihat dari nilai rata-rata, total asset turnover perusahaan dari tahun 2009 sampai dengan tahun 2014 berada di bawah nilai rata-rata. Hal ini menunjukkan bahwa kemampuan perputaran dana yang tertanam dalam keseluruhan aktiva pada satu tahun semakin kecil. Total asset turnover cenderung menurun. Hal ini disebabkan oleh kurang optimalnya perusahaan di dalam mengelola keseluruhan aset yang dimilikinya sehingga manajemen perusahaan sebaiknya mengevaluasi strategi, pemasarannya dan pengeluaran modalnya (investasi).

\section{d. Kinerja Keuangan Pada PT. Gudang Garam, Tbk}

Berikut ini adalah tabel kinerja keuangan PT. Gudang Garam, Tbk dari tahun 2009-2014:

$$
\text { Tabel } 20
$$

Kinerja Keuangan PT. Gudang Garam, Tbk Tahun 2009-2014

Berdasarkan Analisis Rasio Profitabilitas

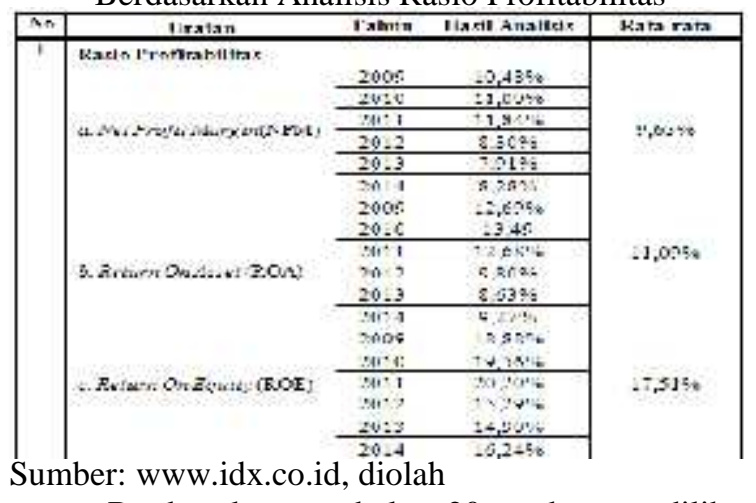

Berdasarkan tabel 20, dapat dilihat perkembangan kinerja keuangan PT. Gudang Garam, Tbk dimulai dari tahun 2009-2014 cenderung mengalami penurunan yang akan dijelaskan melalui analisis rasio pada rasio profitabilitas sebagai berikut:

\section{1) Net Profit Margin (NPM)}

Dilihat dari nilai rata-rata, 3 tahun terakhir yaitu tahun 2012 sampai dengan tahun 2014 berada di bawah nilai rata-rata. Hal ini menunjukkan bahwa semakin kecil persentase perolehan laba bersih dari penjualan. Dan 3 tahun pertama yaitu tahun 2009 sampai dengan tahun 2011 berada di atas nilai rata- rata. Hal ini menunjukkan bahwa semakin besar persentase perolehan laba bersih dari penjualan. Net Profit Margin (NPM) cenderung mengalami penurunan. Hal ini disebabkan oleh kurang optimalnya perusahaan dalam menghasilkan laba bersih dan tingginya beban yang ada seperti beban pokok penjualan, beban usaha dan beban pajak sehingga jumlah laba bersih menjadi sangat sedikit. Selain itu, perusahaan kurang optimal di dalam meningkatkan jumlah penjualan yang dimilikinya. Persentase kenaikan penjualan dari tahun ke tahun selama rentang waktu 6 tahun yaitu tahun 2009 sampai tahun 2014 tidak lebih dari 18\%. Net profit margin juga mengalami penurunan disebabkan oleh jumlah laba bersih yang hampir stabil (tidak adanya kenaikan secara drastis) dari tahun 2009 sampai tahun 2014 namun penjualan perusahaan selama rentang waktu 6 tahun tersebut terus mengalami peningkatan. Hal ini tentu akan mengurangi persentase dari marjin laba bersih.

\section{2) Return On Asset (ROA)}

Dilihat dari nilai rata-rata, 3 tahun awal yaitu tahun 2009 sampai dengan tahun 2011 berada di atas nilai rata-rata. Hal ini menunjukkan semakin besar persentase perolehan laba bersih dari total aktiva perusahaan. Namun dari tahun 2012 sampai dengan tahun 2014 berada di bawah nilai rata-rata. Hal ini menunjukkan semakin kecil persentase perolehan laba bersih dari total aktiva perusahaan. Secara keseluruhan Return on Asset (ROA) mengalami penurunan dikarenakan perputaran aktiva dalam perusahaan kurang baik. Selain itu perusahaan kurang optimal di dalam menghasilkan laba bersih. Return on asset juga mengalami penurunan disebabkan oleh jumlah laba bersih perusahaan yang hampir stabil namun jumlah total aset mengalami peningkatan terus menerus dari tahun 2009 sampai dengan tahun 2014. Hal ini menyebabkan persentase return on asset cenderung mengalami penurunan.

\section{3) Return On Equity (ROE)}

Dilihat dari nilai rata-rata, ROE pada tahun 2009 sampai dengan tahun 2011 berada di atas ratarata. Hal ini menunjukkan semakin besar persentase perolehan laba bersih dari modal yang dimiliki perusahaan. Sedangkan ROE pada tahun 2012 sampai dengan tahun 2014 berada di bawah rata-rata. Hal ini menunjukkan semakin kecil persentase perolehan laba bersih dari modal yang dimiliki perusahaan. Berdasarkan grafik yang ditunjukkan pada gambar 10, secara keseluruhan ROE perusahaan cenderung menurun dikarenakan penurunan kemampuan perusahaan dalam menginvestasikan modal yang dimilikinya dan juga kurang optimalnya perusahaan dalam menghasilkan laba bersih. Besarnya beban pokok penjualan, beban usaha dan beban pajak menyebabkan laba bersih yang diperoleh perusahaan menjadi lebih kecil. Hal ini menyebabkan persentase return on equity menjadi lebih kecil. Selain itu, jumlah laba bersih perusahaan yang hampir stabil kurang mampu mengimbangi jumlah peningkatan modal perusahaan 
yang terus meningkat dari tahun 2009 sampai dengan tahun 2014. Sehingga persentase return on equity cenderung mengalami penurunan.

Dengan demikian dapat disimpulkan bahwa kinerja keuangan yang diukur melalui rasio profitabilitas (net profit margin, return on asset, return on equity) mengalami penurunan disebabkan oleh rasio aktivitas dan rasio solvabilitas (leverage) sehingga hipotesis diterima.

\section{KESIMPULAN DAN SARAN}

\section{Kesimpulan}

a. Tingkat likuiditas PT. Gudang Garam, Tbk cenderung mengalami penurunan. Dilihat dari current ratio, penurunan ini disebabkan oleh pertumbuhan hutang lancar yang besar. Dan apabila dilihat dari quick ratio, penurunan ini disebabkan oleh jumlah persediaan yang besar (di atas 80\%) dari aset lancar. Sehingga jumlah aktiva lancar yang likuid menjadi sedikit.

b. Tingkat solvabilitas PT. Gudang Garam, Tbk cenderung mengalami peningkatan dari tahun ke tahun. Kenaikan ini disebabkan oleh peningkatan hutang perusahaan yang digunakan untuk membiayai modal dan aktiva perusahaan.

c. Tingkat aktivitas PT. Gudang Garam, Tbk cenderung mengalami penurunan dari tahun ke tahun. Dikarenakan kurang optimalnya perusahaan di dalam mengelola aset yang dimilikinya. Namun perputaran persediaan cenderung rata atau sejajar dikarenakan jumlah persediaan cukup besar persentasenya dibanding aset lancar lainnya.

d. Tingkat profitabilitas PT. Gudang Garam, Tbk cenderung menurun dari tahun ke tahun dikarenakan persentase pencapaian laba bersih yang lebih rendah dibandingkan dengan jumlah penjualan, modal dan total aset dari perusahaan.

e. Kinerja keuangan PT. Gudang Garam, Tbk dari tahun 2009 sampai dengan tahun 2014 yang diukur melalui rasio profitabilitas cenderung mengalami penurunan. Penurunan kinerja keuangan disebabkan oleh rasio aktivitas dan rasio solvabilitas (leverage).

\section{Saran}

a. PT. Gudang Garam, Tbk sebaiknya meningkatkan aktiva lancarnya dan menekan persentase kenaikan hutang lancar untuk meningkatkan persentase current ratio dan quick ratio. Serta menekan jumlah persediaan agar aset lancar yang likuid mengalami peningkatan. Hal ini akan berdampak pada quick ratio perusahaan.

b. PT. Gudang Garam, Tbk sebaiknya meningkatkan jumlah modal dan total aset yang dimilikinya. Agar semakin sedikit modal dan aset perusahaan yang dijamin dengan hutang perusahaan.

c. PT. Gudang Garam, Tbk sebaiknya lebih memperhatikan pengelolaan aset-aset yang ada di dalam perusahaan. Selain itu perusahaan harus mengurangi jumlah persediaan yang ada karena persediaan merupakan aset yang tingkat likuidnya paling rendah.

d. PT. Gudang Garam, Tbk sebaiknya meningkatkan persentase penjualan, modal dan juga total aset yang ada untuk meningkatkan persentase profitabilitas perusahaan dan mengurangi semua beban atas pendapatan. Hal ini dapat dilakukan dengan perluasan pangsa pasar dengan tingkat harga yang lebih menguntungkan. Sehingga laba bersih yang dimiliki perusahaan mengalami peningkatan. Yang pada akhirnya berdampak pada kelangsungan hidup perusahaan.

e. PT. Gudang Garam, Tbk sebaiknya meninjau kembali manajemen hutang di mana solvabilitas mengalami peningkatan namun menyebabkan penurunan pada profitabilitas.

f. PT. Gudang Garam, Tbk tetap melakukan analisis rasio keuangan sebagai dasar untuk mengetahui perkembangan perusahaan dan juga pedoman untuk menentukan kebijaksanaan perusahaan dalam mencapai target perusahaan.

g. Bagi peneliti selanjutnya, sebaiknya perlu juga melakukan penelitian dengan menggunakan rasio lain seperti rasio penilaian pasar dan rasio pertumbuhan serta objek penelitian yang digunakan sebaiknya lebih dari satu objek seperti melakukan penelitian pada kelompok industri rokok yang terdaftar di Bursa Efek Indonesia.

\section{E. DAFTAR PUSTAKA}

Astuti, Dewi. 2004. Manajemen Keuangan Perusahaan. Cetakan Pertama. Jakarta: Ghalia Indonesia.

Bursa Efek Indonesia, http://www.idx.co.id: tahun akses 2015

Fahmi, Irhan. 2011. Analisis Kinerja Keuangan. Cetakan Pertama. Bandung: Alfabeta

Harahap. Sofyan Syafri. 2006. Analisis Kritis Atas Laporan Keuangan. Jakarta: PT. Raja Grafindo Persada.

Horne, James C. Van dan John M. Wachowicz. 2012. Prinsip-prinsip Manajemen Keuangan. Edisi XIII, Buku 1. Jakarta: Salemba Empat.

Munawir. 2002. Analisis Laporan Keuangan. Yogyakarta: Liberty.

Sawir, Agnes. 2005. Analisis Kinerja Keuangan dan Perencanaan Keuangan Perusahaan. Jakarta: PT. Gramedia Pustaka Utama.

Sudana, I Made. 2011. Manajemen Keuangan Perusahaan Teori dan Praktik. Jakarta: Penerbit Erlangga.

Sutrisno. 2013. Manajemen Keuangan Teori, Konsep dan Aplikasi. Edisi Pertama. Cetakan Kesembilan. Yogyakarta: Penerbit Ekonisia Kampus Fakultas Ekonomi.

Syamsuddin, Lukman. 2013. Manajemen Keuangan Perusahaan. Edisi Baru. Cetakan Keduabelas. Jakarta: Rajawali Press. 